\title{
An Immunoreactive Protein to Wheat-Germ Agglutinin Antibody Is Induced in Oat Roots Following Invasion of the Cereal Cyst Nematode Heterodera avenae, and by Jasmonate
}

\author{
Y. Oka, ${ }^{1}$ I. Chet, ${ }^{2}$ and Y. Spiegel ${ }^{1}$ \\ ${ }^{1}$ Department of Nematology, Agricultural Research Organization (ARO), The Volcani Center, Bet Dagan \\ 50250; and 'Department of Plant Pathology and Microbiology, The Hebrew University of Jerusalem, The \\ Faculty of Agriculture, Rehovot 76100, Israel \\ Accepted 29 July 1997.
}

\begin{abstract}
A protein that cross-reacts to a wheat-germ agglutinin antibody was induced in oat roots following the invasion of second-stage juveniles $(\mathrm{J} 2)$ of the cereal cyst nematode Heterodera avenae. This protein, designated ASP45, was acid soluble, and its molecular mass was about $45 \mathrm{kDa}$ on a sodium dodecyl sulfate-polyacrylamide gel. ASP45 was induced in both compatible and incompatible interactions between the nematode and the plant, and also in roots by exposure to jasmonic acid (JA) or methyl jasmonate. However, ASP45 was not induced by elicitors of pathogenesis-related proteins, abscisic acid, or wounding. Lipoxygenase activity, which is involved in JA synthesis, was higher in nematode-infected and JA-treated roots than in their noninfected, untreated counterparts. Inhibition of lipoxygenase activity in roots abolished ASP45 induction in the nematode-infected roots. Amino acid sequences similar to that of ASP45 were found in chitinases of poplar tree and Arabidopsis, even though ASP45 showed no chitinase activity. Although the biological role of ASP45 in infected roots is not clear, $\mathrm{JA}$ is suggested to be involved in signal transduction after pathogen invasion of the plant.
\end{abstract}

Additional keywords: H. latipons, lectin.

Plant-parasitic cyst nematodes are sedentary and highly specialized endoparasites. After invasion of host-plant roots, second-stage juveniles (J2) induce syncytia, which are very sophisticated feeding sites (Jones 1981). Syncytium is generally formed by cell-wall degradation of several parenchyma cells near the head of the nematode, which stimulates syncytium formation by injecting a secretion into the cells via the stylet. The syncytium is essential for nematode development, and its integrity depends on continuous stimulation by the nematode.

Plants react defensively to pathogen invasion in several ways. Secondary metabolites, non-proteinaceous compounds, and proteins are usually synthesized in plants following invasion. Phenolic compounds and phytoalexins are examples of small, non-proteinaceous molecular compounds involved in the plant-defense cascade. Hydrolytic and other enzymes such

Corresponding author: Y. Spiegel; E-mail: vpspigl@volcani.agri.gov.il as chitinase, glucanase, and peroxidase, as well as enzyme inhibitors and pathogenesis-related (PR) proteins, are some of the proteinaceous compounds involved in the plant's defense reaction (Bowles 1990). In plant-nematode interactions, several secondary metabolites have been shown to be induced in plants after nematode invasion (Zacheo and Bleve-Zacheo 1995). Several genes or proteins, such as the extensin gene and extensin, a cell-wall component (Niebel et al. 1993; Van der Eycken et al. 1996), and the Tob RB7 gene, which may encode a protein involved in osmotic regulation (Opperman et al. 1994), have been found to be expressed in nematodeinfected roots. PR proteins, including $\beta$-1,3-glucanase and $\beta$ $D$-glucosidase, have been found in leaves of potato plants infected with the potato cyst nematodes Globodera pallida and G. rostochiensis, but the role of these PR proteins in the plant's susceptibility or resistance to the nematodes has not been elucidated (Hammond-Kosack et al. 1989; Rahimi et al. 1993, 1996). Chitinase was induced in leaves of a particular barley cultivar infected with the cereal cyst nematode Heterodera avenae Woll., while this chitinase was depressed in another cultivar infected with the same nematode (Oka et al. 1996). In barley and wheat roots infected with $H$. avenae, several changes in soluble-protein composition were found, but these newly synthesized proteins could have originated from either the plant or the nematode (Oka et al. 1996).

Barley lectin and wheat-germ agglutinin (WGA) have been found to accumulate in barley and wheat roots, respectively, infected with $H$. avenae (Oka et al. 1996). This accumulation was not associated with the plant's resistance or susceptibility to the nematode. These lectins are synthesized in the root tips of barley or wheat, where $\mathrm{J} 2$ of the nematode usually invade, and were also found in the nematode feeding-site region. Interestingly, a commercial WGA bound to the surface of $H$. avenae $\mathrm{J} 2$, whereas the lectin did not bind to the surface of another cereal cyst nematode, $H$. latipons Franklin. The latter species invades mature roots of cereal plants where lectins are absent, and does not cause lectin accumulation in roots.

Lectins highly homogeneous to WGA have been found in embryos of Triticum spp. and other gramineous species such as Brachypodium spp. and Oryzae spp., but not in oat (Avena sativa L.) (Mishkind et al. 1983; Stinissen et al. 1983). Nev- 
ertheless, oat serves as a host plant for several pathotypes of H. avenae (Anderson and Anderson 1982), and is a relatively good host plant for H. latipons (Cohn and Ausher 1973). In a preliminary experiment, proteins of oat roots inoculated with $H$. avenae $\mathrm{J} 2$ were immunoblotted and probed with an antiserum to WGA: a polypeptide band of about $45 \mathrm{kDa}$ reacted with the antiserum whereas, in uninoculated roots, this band was not detected (Oka et al. 1996).

In this study, induction of this protein, designated ASP45, by the nematode and chemical elicitors and its accumulation site in the plant were investigated. Moreover, ASP45 was purified, and its possible role in pathogenesis discussed.

\section{RESULTS}

\section{Effect of H. avenae infection or jasmonic acid (JA) treatment on oat-root protein composition.}

Proteins from oat roots inoculated with $\mathrm{J} 2$ of Ha21 (an Israeli pathotype of $H$. avenae) or exposed to $100 \mu \mathrm{M}$ JA for 4 days were subjected to sodium dodecyl sulfate-polyacrylamide gel electrophoresis (SDS-PAGE), and stained with Coomassie blue G-250. Compared with proteins from uninoculated, untreated oat roots, several new peptide bands appeared in both nematode-infected and JA-treated roots, at 97, 76, 45, and $35 \mathrm{kDa}$ (not shown). In addition, 29- and 22.5-kDa bands appeared in the JA-treated roots. The amount of root protein extracted from the JA-treated plants (approximately $500 \mu \mathrm{g}$ per $\mathrm{ml}$ of extract) was higher than that from nematodeinfected (approximately $400 \mu \mathrm{g} / \mathrm{ml}$ ) and noninfected, untreated plants (approximately $270 \mu \mathrm{g} / \mathrm{ml}$ ).

\section{Induction of ASP45.}

The fractionated root proteins were transferred to a nitro- cellulose membrane, and probed with antibody to WGA. A 45-kDa polypeptide (ASP45) band was detected in protein extracts of roots inoculated with $\mathrm{Ha} 21 \mathrm{~J} 2$ (Fig. 1). This band was not detected in protein extracts of cotyledons, and did not appear on the immunoblot in which nonimmune rabbit serum had been used as the primary antibody (data not shown).

The ASP45 band was detected from 2 to 10 days after inoculation with Ha21 J2, whereas this band was not detected in root extracts from uninoculated seedlings during the experimental period (Fig. 1A).

Root proteins extracted from oat seedlings inoculated with $10,50,100$, or $200 \mathrm{Ha} 21 \mathrm{~J} 2$ per seedling were extracted 4 days after inoculation. The ASP45 band appeared very weakly in root-protein extract from plants inoculated with $10 \mathrm{~J} 2$, its intensity increasing with increasing inoculum levels (Fig. 1B). The ASP45 band was very weak or nonexistent in roots inoculated with $H$. latipons $\mathbf{J} 2$, even at an inoculum level of 200 J2 per seedling (Fig. 1B). ASP45 was induced in a compatible $H$. avenae-oat interaction (cv. Sun II inoculated with Ha12), as well as in incompatible interactions (640318-40-2-1 inoculated with $\mathrm{Ha} 12$ or Ha21, and Sun II inoculated with Ha21) (Fig. 1C).

\section{Chemical treatment and wounding.}

Oat-seedling roots were immersed in chemical solutions for 4 days. An intense ASP45 band was detected only in roots exposed to JA, Ha21-inoculated roots (Fig. 2A,B), and roots exposed to methyl jasmonate (MeJA) (not shown). In wounded roots, or roots exposed to a polyethylene glycol (PEG) 8000 solution used to induce osmotic stress, ASP45 was not detected (Fig. 2B). Only faint bands at 45 and $40 \mathrm{kDa}$ were detected in some treatments (Fig. 2). Immersion of roots in concentration lower than $25 \mu \mathrm{M}$ JA did not induce ASP45

\section{H. latipons}
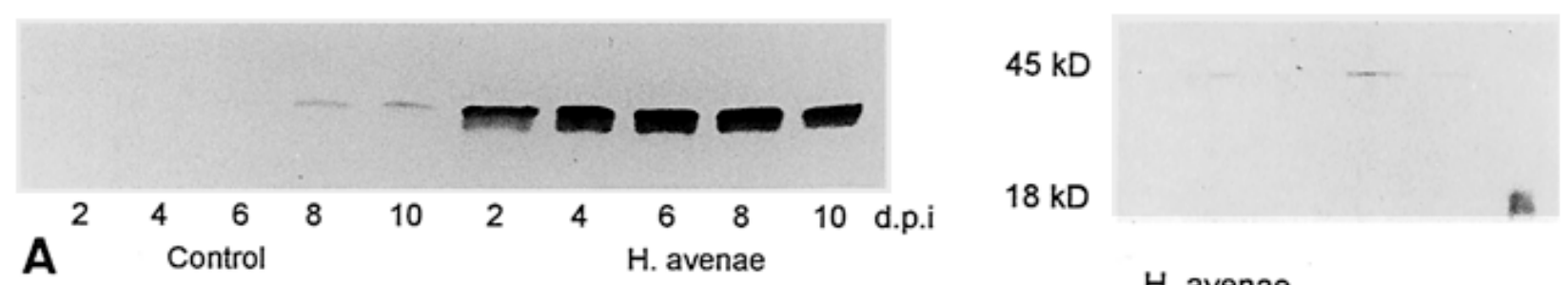

\section{H. avenae}
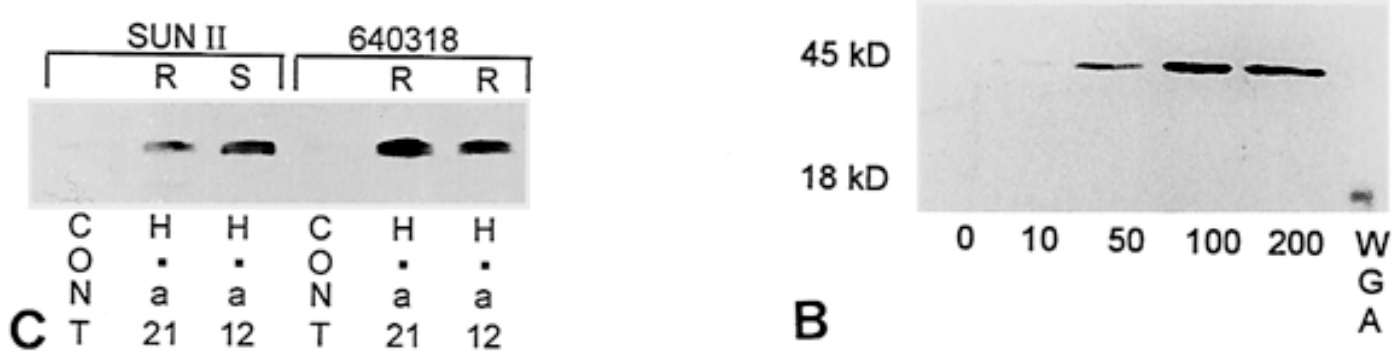

Fig. 1. Immunoblot analysis of oat-root proteins with antiserum to wheat-germ agglutinin (WGA). A, Root proteins extracted at $\mathrm{pH} 2.8$ from uninoculated (control) and Heterodera avenae-inoculated roots, 2, 4, 6, 8, and 10 days post inoculation (d.p.i.). B, Roots inoculated with $H$. avenae or $H$. latipons at inoculum levels of $0,10,50,100$, or 200 per seedling. Root proteins were extracted 4 d.p.i. Commercial WGA (30 ng) was also loaded onto the gel. Molecular mass markers are indicated on the left (kDa). C, Oat cultivars Sun II and 640318-40-2-1 inoculated with H. avenae pathotypes Ha21 or Ha12. Uninoculated roots (CONT) were used as control. R and S: cultivar resistance and susceptibility to the pathotypes, respectively. Root proteins were extracted 4 d.p.i. 
in the experiment (Fig. 2C,D), and the ASP45 band appeared at least $24 \mathrm{~h}$ after immersion in $100 \mu \mathrm{M} \mathrm{JA}$ (Fig. 2E). ASP45 was not detected in oat leaves, the cut ends of which had been immersed in $200 \mu \mathrm{M}$ JA (Fig. 2E). A protein band reacting to antiserum against tobacco acidic chitinase was detected in protein extract of leaves sprayed with $\mathrm{HgCl}_{2}$ solution. The apparent molecular mass of this chitinase was about $30 \mathrm{kDa}$. It was not detected in leaf or root extracts from control, $H$. avenae-infected or $\mathrm{HgCl}_{2}$-treated roots (not shown). Although a higher protein level (approximately $2.4 \mathrm{mg}$ per $\mathrm{ml}$ of extraction) was recorded in JA-treated roots $(200 \mu \mathrm{M}$ for 4 days $)$ extracted at $\mathrm{pH} \mathrm{7.4,} \mathrm{compared} \mathrm{with} \mathrm{those} \mathrm{extracted} \mathrm{at} \mathrm{pH} 2.8$ $(0.5 \mathrm{mg} / \mathrm{ml})$, the ASP45 band was hardly detectable in the former (Fig. 2D).

\section{Lipoxygenase activity.}

Lipoxygenase (LOX, EC 1.13.11.12) activity in uninoculated, Ha21-inoculated, and JA-treated roots was monitored, because LOX is involved in JA synthesis. Before treatment (2 days after germination), activity was relatively low (3.0 $\Delta A_{234}$ - $\left.\min ^{-1} \cdot \mathrm{g} \mathrm{root}^{-1}\right)$, but $24 \mathrm{~h}$ after inoculation or exposure to JA, LOX activity was more than twofold higher than that of uninoculated, untreated roots (Fig. 3A). In the subsequent days, activity in JA-treated and nematode-infected roots was about 5 to 10 times and 3 to 5 times higher, respectively, than that in uninoculated, untreated roots (Fig. 3A).

\section{Inhibition of ASP45 induction.}

Oat roots were treated with butylated hydroxyanisole (BHA), which is an antioxidant and inhibits the synthesis of JA from linolenic acid via lipoxidation by LOX. ASP45 induction in oat roots following $\mathrm{J} 2$ invasion was abolished by exposure of seedling roots to $50 \mu \mathrm{M}$ BHA for $24 \mathrm{~h}$, followed by planting the seedlings in silica sand moistened with the BHA solution prior to inoculation (Fig. 3B). BHA treatment did not inhibit the $\mathrm{J} 2$ invasion of the roots $(5.7 \pm 1.2 \mathrm{~J} 2$ in untreated root tip; $5.3 \pm 0.8 \mathrm{~J} 2$ in BHA-treated root tip). The morphology of BHA-treated, J2-infected roots differed from that of their untreated, J2-infected counterparts: in contrast to the latter (Fig. 3C), the root tips of the BHA-treated, J2infected roots stopped growing and enlarged, and a lateral root emerged (Fig. 3D). BHA treatment did not inhibit root growth of uninoculated roots, nor were the root tips enlarged, but fewer root hairs were observed on the BHA-treated roots (not shown).

\section{Purification and microsequence of ASP45.}

A single band of ASP45 was obtained by anti-WGAcoupled affinity chromatography (Fig. 4A). Its N-terminal amino acid sequence could not be determined due to a blocked $\mathrm{N}$ terminus. Following SDS-PAGE, the stained ASP45 band was digested with Endoproteinase Lys-C in the gel into fragments. These were eluted from the gel, separated by high-
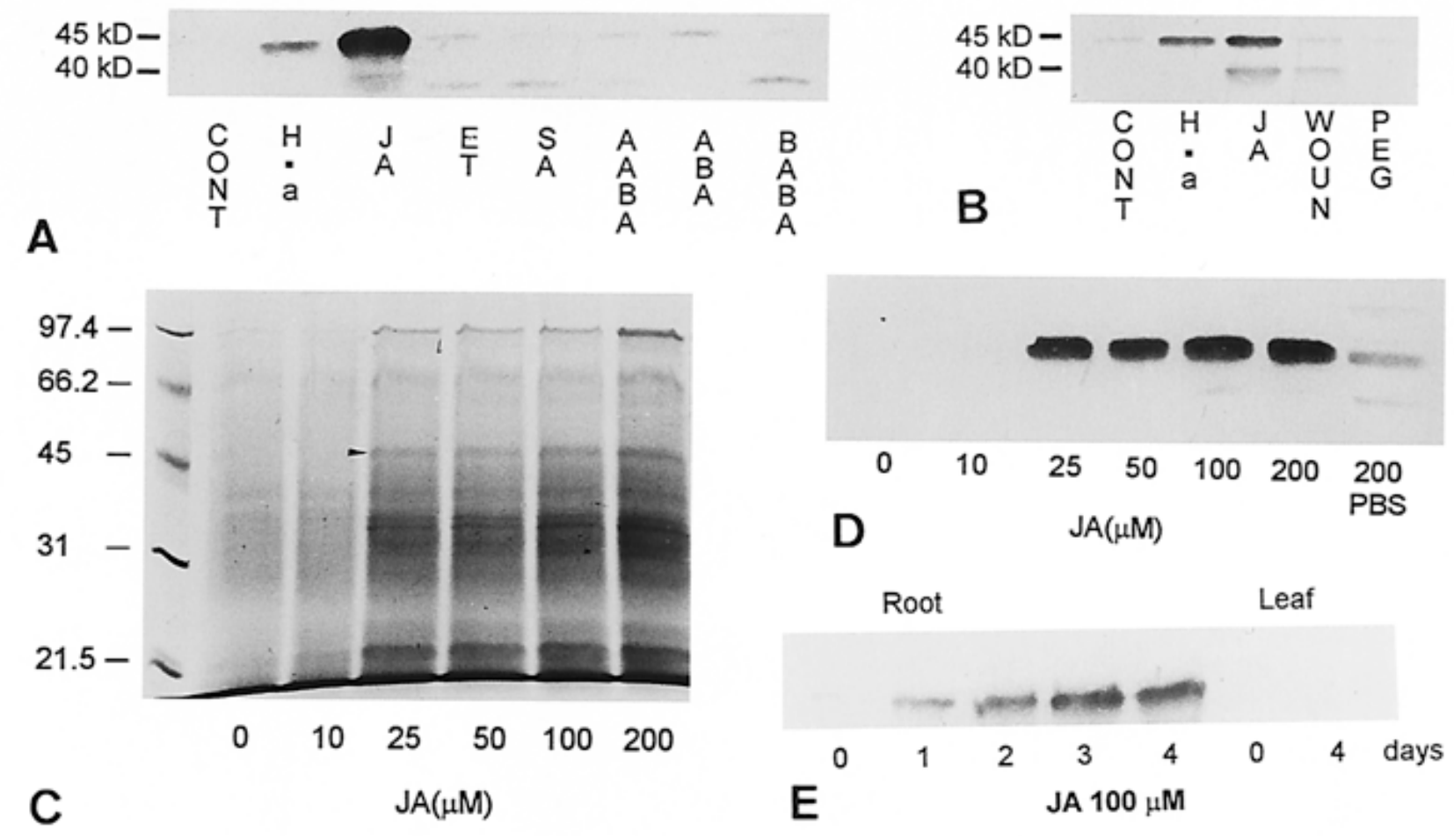

Fig. 2. Analysis of proteins extracted from oat roots. Proteins were extracted 4 days after each treatment at $\mathrm{pH} 2.8$, fractionated by sodium dodecyl sulfate-polyacrylamide gel electrophoresis (SDS-PAGE), and immunoblotted with antiserum to wheat-germ agglutinin. A, Roots were untreated (CONT), inoculated with Heterodera avenae (H.a), or treated with $50 \mu \mathrm{M}$ jasmonic acid (JA), $1 \mathrm{mM}$ ethephon (ET), $5 \mathrm{mM}$ salicylic acid (SA), $5 \mathrm{mM} \alpha-$ aminobutyric acid (AABA), $100 \mu \mathrm{M}$ abscisic acid (ABA), or $5 \mathrm{mM} \beta$-aminobutyric acid (BABA). B, Roots were uninoculated (CONT), inoculated with $H$. avenae (H.a), treated with $100 \mu \mathrm{M}$ jasmonic acid (JA), wounded (WOUN), or treated with $180 \mathrm{~g}$ of polyethylene glycol (PEG) per liter. C, SDSPAGE proteins extracted from roots treated with $0,10,25,50,100$, and $200 \mu \mathrm{M} \mathrm{JA}$. Immunoreactive protein to antiserum to WGA is indicated by an arrow. Molecular mass markers are indicated on the left ( $\mathrm{kDa}$ ). $\mathbf{D}$, Immunoblot of $\mathbf{C}$ and protein extraction with phosphate-buffered saline ( $\mathrm{pH}$ 7.2) from roots treated with $200 \mu \mathrm{M} \mathrm{JA}$. E, Immunoblot of proteins of roots treated with $100 \mu \mathrm{M} \mathrm{JA}$ for $0,1,2$, 3, or 4 days, or proteins of untreated oat leaves or those immersed in $100 \mu \mathrm{M} \mathrm{JA}$ for 4 days. 
pressure liquid chromatography, and subjected to N-terminal microsequencing. The amino acid sequence of one of the peptides was partly homologous to that of the poplar endochitinase win8 (Parsons et al. 1989) and a basic endochitinase of Arabidopsis thaliana (Samac et al. 1990) (Fig. 4B).

\section{Chitinase activity.}

Chitinase (EC 3.2.1.14) activity was measured with $p$ nitrophenyl- $\beta$-D- $N, N^{\prime}, N^{\prime \prime}$-triacetylchitotriose as the substrate. Chitinolytic activity was not detected in extracts of nontreated, $H$. avenae-infected, or JA-treated ( $200 \mu \mathrm{M}$ for 4 days) oat roots, or in purified ASP45.

\section{Immunohistology.}

In JA-treated roots, ASP45 was detected in the intercellular spaces of the vascular cylinder (Fig. 5A). The protein was detected mainly in the intercellular spaces of the cortical cells, and the vascular cylinder of nematode-infected roots, especially on the cell walls of protoxylems (Fig. 5B).

\section{DISCUSSION}

In a previous work, we demonstrated the accumulation of barley lectin and WGA in $H$. avenae-infected barley and wheat roots, respectively (Oka et al. 1996). In the present study, ASP45, which cross-reacts with WGA antiserum, was induced in oat roots following the invasion of $H$. avenae $\mathrm{J} 2$. Lectins that are immunologically related to WGA and exhibit erythrocyte-agglutinating activity have been found in embryos of Triticum spp. and other gramineous species, but not in oat embryos (Mishkind et al. 1983; Stinissen et al. 1983). WGA is a $36-\mathrm{kDa}$ dimer protein, composed of two identical $18-\mathrm{kDa}$ subunits, that has an affinity to $N$-acetylglucosamine oligomers and chitin (Raikhel and Lee 1993). Although WGA
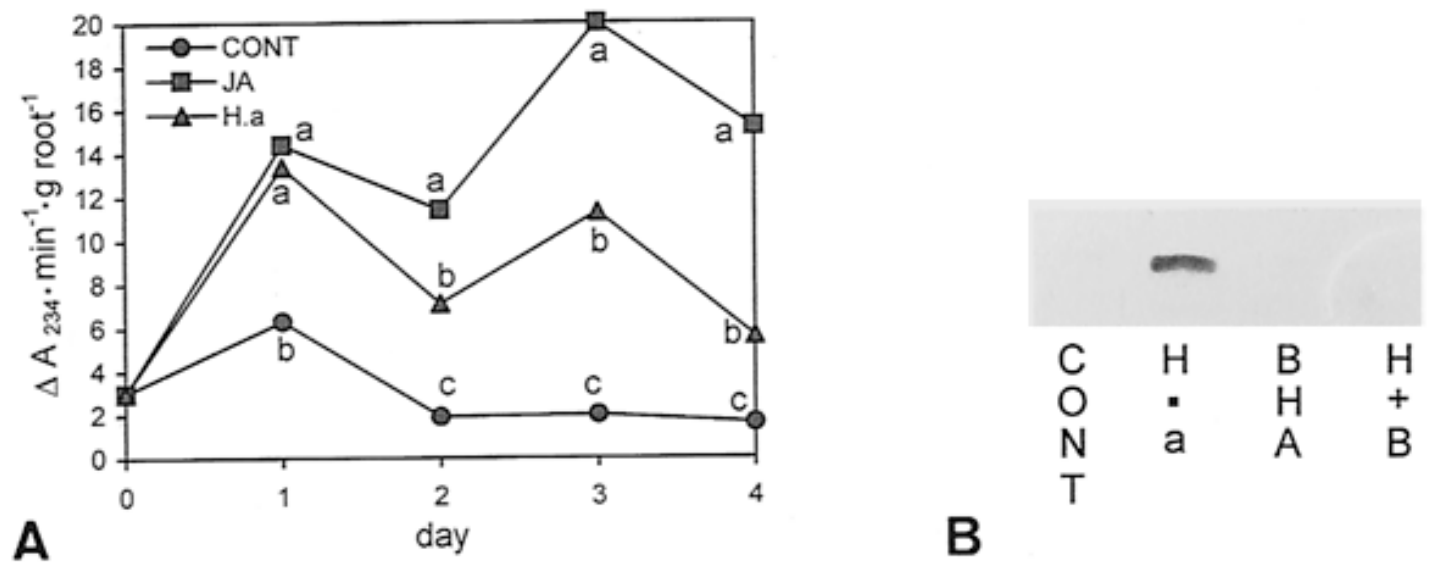

B
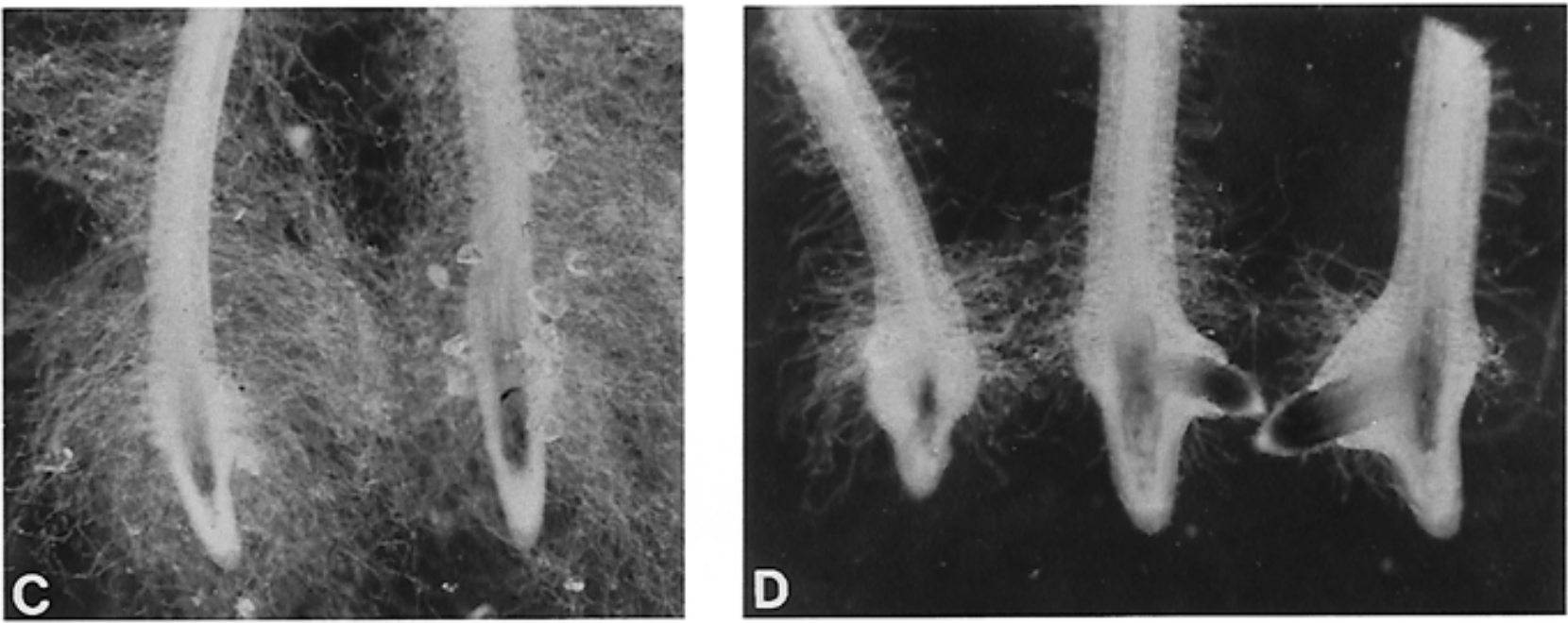

Fig. 3. Lipoxygenase activity in oat roots (A), and effect of butylated hydroxyanisole (BHA) on root proteins (B) and morphology of roots infected with Heterodera avenae (C, D). A, Roots were inoculated with $H$. avenae (H.a), or exposed to $100 \mu \mathrm{M}$ jasmonic acid (JA). Untreated roots (CONT) were used as control. Activity was expressed as change in absorbance at $234 \mathrm{~nm}$ per min, per gram root, with linoleic acid as a substrate. Data are mean values of five replicates. Means in a given day with the same letter do not differ significantly according to least significant difference $(P=0.05)$. $\mathbf{B}$, Analysis of proteins from oat roots immersed in $50 \mu \mathrm{M}$ BHA $24 \mathrm{~h}$ prior to planting in silica sand moistened with BHA. Half of the seedlings w ere inoculated with $H$. avenae, and root proteins were extracted 4 days after inoculation, fractionated by sodium dodecyl sulfate-polyacrylamide gel electrophoresis, and immunoblotted with antiserum to wheat-germ agglutinin. CONT: Untreated, uninoculated roots. H.a: H. avenae-inoculated roots. BHA: BHA-treated roots. H+B: BHA-treated roots inoculated with $H$. avenae. C, Untreated, H. avenae-infected roots. D, BHA-treated, H. avenae-infected roots. Roots were bleached with sodium hypochlorite, then stained with acid fuchsin. 
antibody reacted with ASP45 on an immunoblot, protein extracts from JA-treated roots or purified ASP45 did not agglutinate erythrocytes (Y. Oka, unpublished). On the other hand, ASP45 shares some features with WGA: it is acid soluble, and it is induced by the invasion of $H$. avenae $\mathrm{J} 2$ and by exposure to JA (Y. Oka, unpublished). Several chitin-binding proteins, which have amino acid sequences similar to the WGA repetitive domains, are induced after pathogen invasion or wounding (Raikhel and Lee 1993; Raikhel and Broekaert 1993). Most of these proteins have deleterious effects on insects and/or fungal plant-pathogens (Raikhel and Lee 1993; Raikhel and Broekaert 1993).

ASP45 was induced only by exposure to jasmonates (JA and MeJA) among several chemicals tested in this work. Exposure of oat seedlings to $25 \mu \mathrm{M} \mathrm{JA}$ inhibits root but not cotyledon growth. Abscisic acid (ABA; an enhancer of WGA

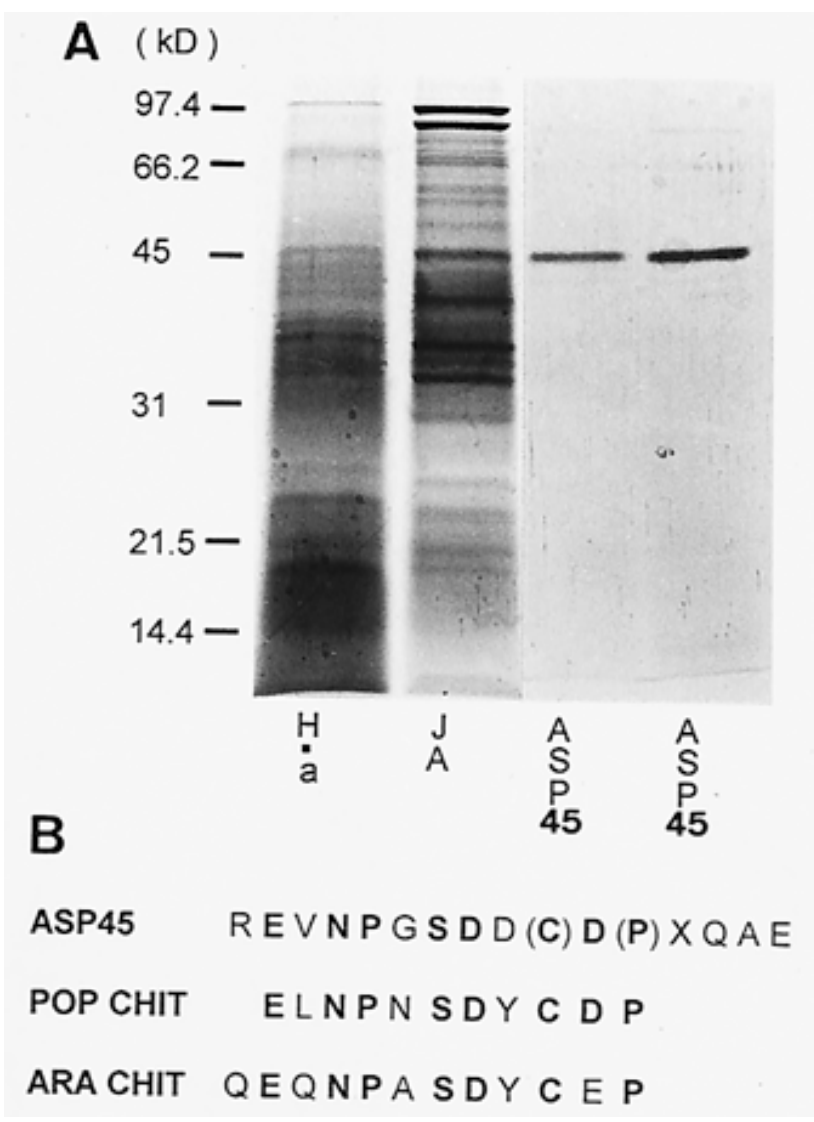

Fig. 4. Purification of an oat-root protein (ASP45) cross-reactive to wheat-germ agglutinin (WGA) antiserum, and its amino acid sequence. A, Oat roots were inoculated with Heterodera avenae, or treated with $100 \mu \mathrm{M}$ jasmonic acid (JA) for 4 days, and root proteins were extracted at $\mathrm{pH}$ 2.8. ASP45 was purified in an affinity column coupled with WGA antiserum. Proteins from roots inoculated with $H$. avenae (H.a) or treated with $\mathrm{JA}$, and purified ASP45 from $H$. avenae-infected roots (right) or JA-treated roots (left) were subjected to sodium dodecyl sulfate-polyacrylamide gel electrophoresis. Molecular mass markers are indicated on the left $(\mathrm{kDa})$. B, Amino acid sequence of a peptide from ASP45. Regions of homology between two plant chitinases and the ASP45 peptide are in bold. Homology at amino acid level was $72 \%$ with poplar endochitinase win8 (POP CHIT) (Parsons et al. 1989), and 61\% with a basic chitinase of Arabidopsis thaliana (ARA CHIT) (Samac et al. 1990). Amino acid in brackets represent uncertain determinations. X: not determined. synthesis), however, inhibits both root and cotyledon growth more severely than JA at the same concentration (Y. Oka, unpublished). Therefore, it is not likely that ASP45 induction was due to root-growth inhibition. In nematode-infected oat roots, ABA and ethylene levels increased in both tolerant and non-tolerant cultivars (Volkmar 1991), but this phenomenon may not be directly related to ASP45 induction, because treatment with ABA, or ethephon, which should release ethylene, did not induce ASP45.

JA and MeJA have been suggested to serve as signal molecules in plant-defense responses (Gundlach et al. 1992; Reinbothe et al. 1994; Creelman and Mullet 1995). Exogenous JA or MeJA induces several new proteins in plants (Sembder and Parthier 1993), some of which have a deleterious effect on pathogens (Andresen et al. 1992; Epple et al. 1995; Penninckx et al. 1996). Enzymes involved in phytoalexin biosynthesis are also induced by jasmonates (Gundlach et al. 1992; Muller et al. 1993). Spraying with JA or MeJA protected tomato and potato plants from Phytophthora infestans (Cohen et al. 1993). Protease inhibitors that inhibit fungal and insect growth are also induced by JA (Farmer et al. 1992); however, their molecular masses are usually smaller than $25 \mathrm{kDa}$.

Exogenous JA is also capable of increasing LOX activity in plants (Bell and Mullet 1991; Grimes et al. 1992; Rafi et al. 1996), which is also thought to be involved in plant protection (Siedow 1991) and JA synthesis (Sembdner and Parthier 1993). In oat leaves, higher LOX was involved in a resistance reaction to the fungus Puccinia coronata (Yamamoto and Tani 1986). JA and LOX are located mainly in actively growing young organs such as the cotyledon or root tip (Meyer et al. 1984; Creelman and Mullet 1995). The mechanism of ASP45 induction in oat roots after nematode invasion is thought to progress as follows: fatty acids are released from the plant-cell membrane, due to nematode migration, which causes cell disruption, the plant's hypersensitive reaction, or initiation of syncytium formation, in which cell-wall degradation takes place. LOX and other enzymes present in the root tip then synthesize JA from the fatty acids. JA induces ASP45, and increases LOX activity, which in turn increases JA synthesis. This hypothesis was supported by the facts that the nematode invasion that occurs intracellularly increased LOX activity, and ASP45 induction was abolished by BHA, an antioxidant that inhibits LOX activity. Abolishment of a JA-inducible gene by treatment with LOX inhibitors has also been reported in soybean plants (Staswick et al. 1991). Invasion by another cereal cyst nematode species, $H$. latipons, did not induce ASP45 in oat roots. In contrast to $H$. avenae $\mathrm{J} 2$, which invade root tips, $H$. latipons $\mathrm{J} 2$ invade mature parts of the cereal root (Mor et al. 1992a, 1992b) where LOX activity may be low (Altschuler et al. 1989). This difference may result in insufficient JA synthesis to induce ASP45 in the roots. In barley and wheat roots infected with $H$. avenae, or treated with JA, no immunoreactive protein with WGA antiserum was detected by immunoblotting, except for barley lectin and WGA (Y. Oka, unpublished).

Although several JA-inducible genes can also be induced by wounding (Hildmann et al. 1992) and wounding increases endogenous JA (Creelman et al. 1992), artificial wounding of oat roots did not induce ASP45. In soybean roots, the mRNA level of VSP- $\alpha$ was not increased by wounding, although it was elevated by JA (Mason and Mullet 1990). An MeJA- 
inducible plant defensin was also not induced in A. thaliana by wounding (Penninckx et al. 1996).

Amino acid sequences similar to that of ASP45 were found in chitinases of poplar tree (Parsons et al. 1989) and A. thaliana (Samac et al. 1990). These enzymes are induced in many plant species upon invasion by pathogens or under stressful conditions, and play a role in plant defense (Schlumbaum et al. 1986; Collinge et al. 1993). Chitinases are induced not only by pathogen attack or stress, but also by treatment with chemical elicitors, such as salicylic acid and ethylene. However, chitinase has never been reported to be induced by jasmonate, which is a senescence-promoting substance, along with ethylene and ABA. Several chitinases, or their genes, have been isolated in other cereals such as barley (Jacobsen et al. 1990; Kragh et al. 1990), maize (Nasser et al. 1988), rice (Nishizawa and Hibi 1991), and wheat (Molano et al. 1979), either from leaves or grains. A 29.8-kDa chitinase has been found in oat leaves (Fink et al. 1988). In our study, a chitinase that seems to be identical to that isolated by Fink et al. (1988) was detected in oat leaves sprayed with $\mathrm{HgCl}_{2}$. Molecular masses of these cereals, as well as those of other plant chitinases, are between 25 and $35 \mathrm{kDa}$. The apparent molecular mass of ASP45 is $45 \mathrm{kDa}$, which is larger than that of plant chitinases. Moreover, extracts of $H$. avenae-infected or JAtreated roots and purified ASP45 did not show chitinase activity. Class I chitinases have an N-terminal cysteine-rich domain homologous to WGA, but immunological crossreactivity of WGA to chitinase has not been reported.

At this point, ASP45's role in the host-pathogen interaction can only be speculated upon. However, this protein cannot be directly related to the resistance reaction of oat to $H$. avenae, since ASP45 was induced in both compatible and incompatible oat $-H$. avenae interactions. Since the effect of exogenous jasmonates on plants has been mainly investigated with plant leaves, reports on the effects of JA on root gene expression are very limited (Melan et al. 1993; Mason and Mullet 1990). To the best of our knowledge, ASP45 is the first pro- tein induced in plant roots by jasmonate, as well as by a plantroot pathogen.

\section{MATERIALS AND METHODS}

\section{Nematodes.}

The Israeli pathotype of $H$. avenae, Ha21 (Mor et al. 1992a) was used in all experiments, if not otherwise specified. $\mathrm{J} 2$ of Ha21 were hatched from newly formed, dark brown cysts collected from a culture maintained on wheat. Cysts of $H$. avenae pathotype Ha12 were provided by R. Rivoal, Institut National de la Recherche Agronomique, Le Rheu, France. Cysts were surface sterilized for 3 min with a $1 \%$ sodium hypochlorite solution mixed with Tween $20(0.01 \%)$, followed by soaking for $10 \mathrm{~min}$ in a solution of $3 \%$ (vol/vol) $\mathrm{H}_{2} \mathrm{O}_{2}$ mixed with $40 \%$ ethanol $(1: 1 ; \mathrm{vol} / \mathrm{vol})$, and then washing thoroughly with sterilized water. For hatching, surfacesterilized cysts were placed on a $60-\mu$ m nylon mesh, which was immersed in a $20-\mathrm{ml}$ bottle filled with $5 \mathrm{ml}$ of water, and maintained at $15 \pm 1^{\circ} \mathrm{C}$. After approximately 2 weeks, hatched $\mathrm{J} 2$ were collected daily and stored at $4^{\circ} \mathrm{C}$ for no longer than 3 weeks before use.

\section{Plants.}

Oat cultivars Saya 4, Sun II, and 640318-40-2-1 were used. Saya 4 is a local cultivar, whereas Sun II and 640318-40-2-1 were from the International Test Collection for $H$. avenae (Anderson and Anderson 1982). All three cultivars are resistant to Ha21 (Mor et al. 1992a), while Sun II is susceptible and Saya 4 and 640318-40-2-1 are resistant to Ha12 (Anderson and Anderson 1982; Y. Oka, unpublished ). Saya 4 was used in all experiments, unless otherwise specified. Hulled oat seeds were surface sterilized for $15 \mathrm{~min}$ in a $0.1 \%$ $\mathrm{HgCl}_{2}$ solution mixed with Tween $20(0.01 \%)$, followed by extensive washing with sterilized water. The seeds were germinated at $20^{\circ} \mathrm{C}$ on a moist filter paper in a petri dish. When the primary root was about $1.5 \mathrm{~cm}$ long, 50 seedlings were
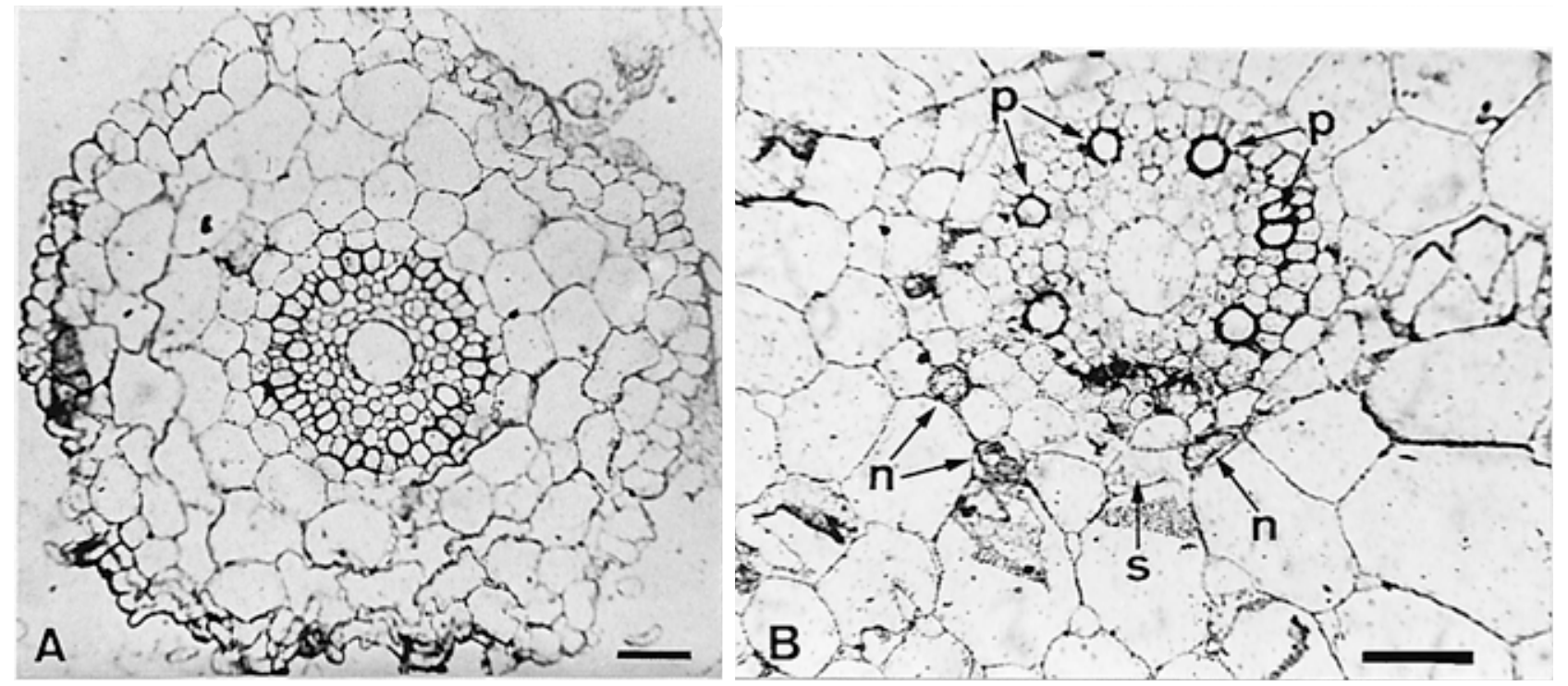

Fig. 5. Immunolabeling of an oat-root protein (ASP45) cross-reactive to wheat-germ agglutinin antiserum on oat (cv. Saya 4) root sections. A, Root section, 4 days after treatment with jasmonic acid. B, Root section, 4 days after inoculation with Heterodera avenae. n: nematode. p: protoxylem. s: initial syncytium. Bars $=50 \mu \mathrm{m}$. 
planted in a $150-\mathrm{ml}$ plastic pot filled with silica sand, and then inoculated with $\mathrm{J} 2$ of $\mathrm{Ha} 21$, Ha12, or H. latipons at various inoculum levels. Uninoculated seedlings served as controls. After planting, seedlings were kept at $15 \pm 1{ }^{\circ} \mathrm{C}$ under 11 -h days.

\section{Chemical treatments and wounding.}

Oat seedling roots (about $1.5 \mathrm{~cm}$ long) were immersed in 5 $\mathrm{ml}$ of $10,25,50,100$, or $200 \mu \mathrm{M} \mathrm{JA}, 100 \mu \mathrm{M}$ MeJA, $5 \mathrm{mM}$ salicylic acid (pH 5.0 with $\mathrm{NaOH}), 100 \mu \mathrm{M}$ ABA, 1 mM 2chloroethyl phosphonic acid (ethephon), PEG 8000 (180 $\mathrm{g} /$ liter), or $5 \mathrm{mM} \alpha$ - or $\beta$-aminobutyric acid. The plants were incubated at $15^{\circ} \mathrm{C}$ up to 4 days in a petri dish $(9 \mathrm{~cm}$ diameter $)$ containing solutions and a filter paper. In a separate experiment, roots (about $1.0 \mathrm{~cm}$ long) of oat seedlings were incubated with $5 \mathrm{ml}$ of $50 \mu \mathrm{M}$ BHA in a petri dish at $15^{\circ} \mathrm{C}$ for 24 $\mathrm{h}$, and then planted in a $120-\mathrm{ml}$ plastic pot filled with silica sand moistened with $50 \mu \mathrm{M}$ BHA. Half of the seedlings were inoculated with $100 \mathrm{Ha} 21 \mathrm{~J} 2$ per seedling.

Leaves and roots of 3-week-old oat plants were sprayed and soil drenched, respectively, with a $0.2 \% \mathrm{HgCl}_{2}$ solution mixed with $0.01 \%$ Tween 20 , or leaves were cut and their cut ends were immersed in $200 \mu \mathrm{M} \mathrm{JA}$.

For wounding, root tips $(1 \mathrm{~mm})$ of the seedlings were cut with a blade, and the seedlings were incubated for 4 days on a moist filter paper in a petri dish at $15 \pm 1{ }^{\circ} \mathrm{C}$.

$\mathrm{ABA}, \mathrm{BHA}$, and JA were first dissolved in a small volume of ethanol (less than $0.1 \%$, vol/vol) before use. All chemicals were purchased from Sigma (St. Louis, MO), except for BHA, which was purchased from BDH (Poole, UK).

\section{Protein extraction.}

Proteins were extracted from cotyledon, leaf, or root of oat seedlings in an acid buffer ( $84 \mathrm{mM}$ citric acid, $14 \mathrm{mM} \mathrm{2-}$ mercaptoethanol, $32 \mathrm{mM} \mathrm{Na}_{2} \mathrm{HPO}_{4}, \mathrm{pH} 2.8$ ) or a $10 \mathrm{mM}$ phosphate buffer ( $\mathrm{pH}$ 7.2) with $1 \mathrm{ml}$ per $\mathrm{g}$ of tissue in an icechilled mortar and pestle, 4 days after inoculation or chemical treatment. The extracts were centrifuged at $15,000 \times g$ for 25 min at $4^{\circ} \mathrm{C}$, and supernatants were collected and stored at $-20^{\circ} \mathrm{C}$ until use.

\section{SDS-PAGE and immunoblotting.}

Protein extracts (approximately $10 \mu \mathrm{g}$ ) were boiled for 5 min in a sample buffer $(1: 1, \mathrm{vol} / \mathrm{vol})$ [125 mM Tris-base, $20 \%$ (vol/vol) glycerol, $2 \%$ (wt/vol) SDS, $2 \%$ (vol/vol) 2-mercaptoethanol and $0.02 \%$ (wt/vol) bromphenol blue, $\mathrm{pH}$ 6.8], and then loaded onto a $1.5-\mathrm{mm}$-thick $3.9 \%$ stacking gel, and fractionated in a $12 \%$ separating gel at $120 \mathrm{~V}$ with a Mini Protean II apparatus (Bio-Rad, Hercules, CA). The proteins in the gel were stained with Coomassie blue G-250 (Serva, Heidelberg, Germany) (Neuhoff et al. 1988), or transferred to a nitrocellulose membrane with a Bio Trans Midi apparatus (Gelman Sciences, Ann Arbor, MI) (Towbin et al. 1979). Proteins reacting with WGA antiserum on the membrane were visualized with an ECL kit (Amersham, Buckinghamshire, UK) according to the manufacturer's instructions. Antiserum to Triticum aestivum lectin (Sigma) diluted 1:3,000 was used as the primary antibody, and peroxidase-conjugated anti-rabbit IgG (Sigma) diluted 1:3,000 was used as the secondary antibody. Binding specificity of the antiserum to ASP45 was checked by replacing the primary antiserum with nonimmune rabbit se- rum. To detect chitinase, antiserum raised against tobacco acidic chitinase was used as the primary antibody, and visualization was performed with the aforementioned ECL kit. The antiserum to tobacco acidic chitinase was a gift from R. Fluhr, Department of Plant Genetics, Weizmann Institute of Science, Rehovot, Israel.

\section{LOX activity assay.}

To measure LOX activity, proteins in $0.4 \mathrm{~g}$ of oat roots inoculated with $100 \mathrm{~J} 2$ per seedling, roots treated with $100 \mu \mathrm{M}$ $\mathrm{JA}$, or untreated, uninoculated control roots were extracted in $0.7 \mathrm{ml}$ of $0.2 \mathrm{M}$ sodium-phosphate buffer ( $\mathrm{pH}$ 6.5) mixed with $0.1 \%$ Triton X-100. The homogenate was centrifuged as described. Root extract $(20 \mu \mathrm{l})$ was added to $980 \mu \mathrm{l}$ of the substrate solution (Peever and Higgins 1989), and activity was measured spectrophotometrically at $234 \mathrm{~nm}$ with linoleic acid (Sigma) as the substrate. The activity was expressed as a change in absorbance at $234 \mathrm{~nm}$ per min per gram root $\left(\Delta A_{234}\right.$ $\left.\cdot \min ^{-1} \cdot \mathrm{g} \mathrm{root}^{-1}\right)$.

\section{Chitinase activity assay.}

Chitinolytic activity of purified ASP45, and extracts of JAtreated, $H$. avenae-infected, and nontreated oat roots were measured as in Chernin et al. (1995), with $p$-nitrophenyl- $\beta$-D$N, N^{\prime}, N^{\prime \prime}$-triacetylchitotriose (Sigma).

\section{Protein purification and amino-acid sequencing.}

Proteins of oat roots exposed to $100 \mu \mathrm{M}$ JA for 4 days were extracted in the acid buffer in the presence of protease inhibitors: $1 \mathrm{mM}$ Pefablock (Boehringer, Mannheim, Germany), 10 $\mu \mathrm{M}$ E-64 (Sigma), and $1 \mathrm{ng}$ per $\mathrm{ml}$ of pepstatin (Sigma). The extract was then centrifuged $(15,000 \times \mathrm{g})$ for $25 \mathrm{~min}$ at $4^{\circ} \mathrm{C}$, dialyzed against phosphate-buffered saline (PBS) at $4^{\circ} \mathrm{C}$ overnight, and centrifuged again, and the supernatant was collected. ASP45 was purified by affinity chromatography by the method of Kenney et al. (1988) with some modifications: 5 $\mathrm{mg}$ of the antiserum to WGA was coupled with $0.4 \mathrm{mg}$ of $\mathrm{N}$ hydroxysuccinimide ester active Sepharose gel (Sigma) in a coupling buffer $\left(0.1 \mathrm{M} \mathrm{NaHCO}_{3}, 0.5 \mathrm{M} \mathrm{NaCl}\right.$, pH 7.0) overnight at $4{ }^{\circ} \mathrm{C}$. The reactive sites of the gel were blocked for $1 \mathrm{~h}$ with $0.1 \mathrm{ml}$ of $1.0 \mathrm{M}$ ethanolamine, $\mathrm{pH}$ 8.0. The gel matrix coupled with the antiserum was washed with three cycles $(5$ min each) of acetate buffer ( $0.1 \mathrm{M} \mathrm{NaCOOH}, 0.5 \mathrm{M} \mathrm{NaCl}, \mathrm{pH}$ 4.0) and the coupling buffer. Root protein extract $(5 \mathrm{ml})$ was incubated with $1 \mathrm{ml}$ of the gel coupled with the antiserum at room temperature for $20 \mathrm{~min}$, with gentle agitation. The gel was washed with PBS, and bound protein was eluted with an elution buffer $(0.1 \mathrm{M}$ glycine/ $\mathrm{HCl}, \mathrm{pH} 2.5)$. The elution was immediately neutralized with $2 \mathrm{M}$ Tris- $\mathrm{HCl}, \mathrm{pH} 8.3$, dialyzed at $4^{\circ} \mathrm{C}$ against deionized water, and lyophilized. Amino acid microsequencing of purified protein was performed at the Protein Research Center, Technion Israel Institute of Technology, in Haifa, Israel.

\section{Tissue processing for light and electron microscopy.}

Hulled oat seeds were surface sterilized with $0.1 \% \mathrm{HgCl}_{2}$ as described earlier. The seeds were germinated at $20^{\circ} \mathrm{C}$ on $1 \%$ water agar. Ha21 J2 were surface sterilized in a $0.05 \%$ (wt/ vol) tetracycline solution for $15 \mathrm{~min}$, followed by a $0.001 \%$ $\mathrm{HgCl}_{2}$ solution for $1 \mathrm{~min}$, and then washed extensively with sterilized water. About $50 \mathrm{~J} 2$ were put near the root tip of an 
oat seedling on the water agar. Small (2 mm long) segments were cut from $\mathrm{J} 2$-infected roots, or the equivalent part of noninoculated roots, 4 days after inoculation, and fixed in $2.5 \%$ glutaraldehyde in $0.1 \mathrm{M}$ phosphate buffer $(\mathrm{pH} 7.2)$ overnight at $4^{\circ} \mathrm{C}$. After fixation, segments were washed $2 \times 10 \mathrm{~min}$ in the phosphate buffer, and then dehydrated in a dilution series of ethanol. The segments were soaked overnight in 50\% (vol/ vol) LR White resin (Sigma) in ethanol, and transferred to $100 \%$ resin with two changes per $4 \mathrm{~h}$. Segments in the resin were polymerized in gelatin capsules at $50^{\circ} \mathrm{C}$ for 24 to $48 \mathrm{~h}$. Sections $(2.5 \mu \mathrm{m})$ for light microscopy were cut, and adhered to glass slides coated with 3-aminopropyltriethoxysilane (Sigma) (Erickson et al. 1993).

\section{Immunogold labeling and silver enhancement.}

Immunogold labeling and silver enhancement were performed according to the method of Erickson et al. (1993) with some modifications. Sections for light microscopy were covered for 30 min with blocking buffer containing 5\% (wt/vol) skim milk dissolved in PBS with $0.1 \%$ Tween 20 (PBS-T), and then covered with antiserum to WGA diluted 1:1,000 in the blocking buffer for $1.5 \mathrm{~h}$, followed by rinses $(3 \times 5 \mathrm{~min})$ in PBS-T. The sections were covered for $1 \mathrm{~h}$ with 10 -nm goldconjugated anti-rabbit IgG (Sigma) diluted 1:200 in PBS-T, rinsed $3 \times 5 \mathrm{~min}$ in PBS-T, and then fixed for $30 \mathrm{~min}$ in $2.5 \%$ glutaraldehyde in $100 \mathrm{mM}$ phosphate buffer ( $\mathrm{pH}$ 7.2). The gold-labeled sections were rinsed in water, and silver enhancement was performed with the Silver Enhancing Kit (Bio Cell, Cardiff, UK), according to the manufacturer's instructions. Specificity of labeling with the polyclonal antibody was assessed by replacing the primary antibody with (i) preimmune serum and (ii) buffer.

\section{ACKNOWLEDGMENTS}

We thank R. Rivoal and R. Fluhr for providing cysts of $H$. avenae and antiserum to tobacco chitinase, respectively, and M. Mor for technical assistance in the microscope work. This study was supported by a grant from the Chief Scientist, The Ministry of Agriculture.

\section{LITERATURE CITED}

Altschuler, M., Collins, G. B., and Hildebrand, D. F. 1989. Developmental expression of lipoxygenases in soybeans. Plant Sci. 63:151158.

Anderson, S., and Anderson, K. 1982. Suggestions for determination and terminology of pathotypes and genes for resistance in cystforming nematodes, especially Heterodera avenae. EPPO Bull. 12: 379-386.

Andresen, I., Becker, W., Schluter, K., Burges, J., Parthier, B., and Apel, K. 1992. The identification of leaf thionin as one of the main jasmonate-induced proteins of barley (Hordeum vulgare). Plant Mol. Biol. 19:193-204.

Bell, E., and Mullet, J. E. 1991. Lipoxygenase gene expression is modulated in plants by water deficit, wounding, and methyl jasmonates. Mol. Gen. Genet. 230:456-462.

Bowles., J. 1990. Defense-related proteins in higher plants. Annu. Rev. Biochem. 59:873-907.

Chernin, L., Ismailov, Z., Haran, S., and Chet, I. 1995. Chitinolytic Enterobacter agglomerans antagonistic to fungal plant pathogens. J. Appl. Environ. Microbiol. 61:1720-1726.

Cohn, E., and Ausher, R. 1973. Longidorus cohni and Heterodera latipons, economic nematode pests of oat in Israel. Plant Dis. Rep. 57: 53-54.

Cohen, Y., Gisi, U., and Niderman, T. 1993. Local and systemic protection against Phytophthora infestans induced in potato and tomato plants by jasmonic acid and jasmonic methyl ester. Phytopathology 83:1054-1062.

Collinge, D. B., Kragh, K. M., Mikkelsen, J. D., Nielsen, K. K., Rasmussen, U., and Vad, K. 1993. Plant chitinases. Plant J. 3:31-40.

Creelman, R. A., and Mullet, J. E. 1995. Jasmonic acid distribution and action in plants: Regulation during development and response to biotic and abiotic stress. Proc. Natl. Acad. Sci. USA 92:4114-4119.

Creelman, R. A., Tierney, M. L., and Mullet, J. E. 1992. Jasmonic acid/ methyl jasmonate accumulate in wounded soybean hypocotyls and modulate wound gene expression. Proc. Natl. Acad. Sci. USA 89: 4938-4941.

Epple, P., Apel, K., and Bohlmann, H. 1995. An Arabidopsis thaliana thionin gene is inducible via a signal transduction pathway different from that for pathogenesis-related proteins. Plant Physiol. 109:813820 .

Erickson, P. A., Lewis, G. P., and Fisher, S. K. 1993. Postembedding immunocytochemical techniques for light and electron microscopy. Pages 283-310 in: Methods in Cell Biology. Vol. 37. Antibodies in Cell Biology. D. J. Asai, ed. Academic Press, San Diego, CA.

Farmer, E. E., Johnson, R. R., and Ryan, C. A. 1992. Regulation of expression of protease inhibitor genes by methyl jasmonate and jasmonic acid. Plant Physiol. 98:995-1002.

Fink, W., Liefland, M., and Mendgen, K. 1988. Chitinases and $\beta-1,3-$ glucanase in the apoplastic compartment of leaves (Avena sativa $\mathrm{L}$.). Plant Physiol. 88:270-275.

Grimes, H. D., Koetje, D. S., and Franceschi, V. R. 1992. Expression, activity, and cellular accumulation of methyl jasmonate-responsive lipoxygenase in soybean seedlings. Plant Physiol. 100:433-443.

Gundlach, H., Muller, M. J., Kutchan, T. M., and Zenk, M. H. 1992. Jasmonic acid is a signal transducer in elicitor-induced plant cell cultures. Proc. Natl. Acad. Sci. USA 89:2389-2393.

Hammond-Kosack, K. E., Atkinson, H. J., and Bowles, J. 1989. Systemic accumulation of novel proteins in the apoplast of the leaves of potato plants following root invasion by the cyst-nematode Globodera rostochiensis. Physiol. Mol. Plant Pathol. 35:495-506.

Hildmann, T., Ebneth, M., Pena-Cortes, H., Sanchez-Serrano, J. J., Willmitzer, L., and Prat, S. 1992. General roles of abscisic acid in gene activation as a result of mechanical wounding. Plant Cell 4:11571170 .

Jacobsen, S., Mikkelsen, J. D., and Hejgaard, J. 1990. Characterization of two antifungal endochitinases from barley grain. Physiol. Plant. 79: 554-562.

Jones, M. G. K. 1981. Host cell responses to endoparasitic nematode attack: Structure and function of giant cells and syncytia. Ann. Appl. Biol. 97:353-372.

Kenney, A., Goulding, L., and Hill, C. 1988. The design, preparation, and use of immunopurification reagents. Pages 99-110 in: Methods in Molecular Biology. Vol. 3. New Protein Techniques. J. M. Walker, ed. Humana Press, Clifton, NJ.

Kragh, K. M., Jacobsen, S., and Mikkelsen, J. D. 1990. Induction, purification and characterization of barley leaf chitinase. Plant Sci. 71:5568.

Mason, H. S., and Mullet, J. E. 1990. Expression of two soybean vegetative storage protein genes during development and in response to water deficit, wounding, and jasmonic acid. Plant Cell 2:569-579.

Melan, M. A., Dong, X., Endara, M. E., Davis, K. R., Ausubel, F. M., and Peterman, T. K. 1993. An Arabidopsis thaliana lipoxygenase gene can be induced by pathogens, abscisic acid, and methyl jasmonate. Plant Physiol. 101:441-450.

Meyer, A., Miersch, O., Buttner, C., Dathe, W., and Sembdner, G. 1984. Occurrence of the plant growth regulator jasmonic acid in plants. J. Plant Growth Regul. 3:1-8.

Mishkind, M. L., Palevitz, B. A., and Raikhel, N. V. 1983. Localization of wheat germ agglutinin-like lectins in various species of the Gramineae. Science 220:1290-1292.

Molano, J., Polachech, I., Duran, A., and Cabib, E. 1979. An endochitinase from wheat germ. Activity on nascent and preformed chitin. J. Biol. Chem. 254:4901-4907.

Mor, M., Cohn, E., and Spiegel, Y. 1992a. Phenology, pathogenicity and pathotypes of cereal cyst nematodes, Heterodera avenae and $H$. latipons (Nematoda: Heteroderidae) in Israel. Nematologica 38:494-501.

Mor, M., Fahn, A., and Spiegel, Y. 1992b. Morphological and cytological changes induced in cereal roots by the cereal cyst nematodes Heterodera avenae and $H$. latipons. (Abstr.) Isr. J. Bot. 41:108. 
Muller, M. J., Brodschelm, W., Spannagl, E., and Zenk, M. H. 1993. Signaling in the elicitation process is mediated through the octadecanoid pathway leading to jasmonic acid. Proc. Natl. Acad. Sci. USA 90:7490-7494.

Nasser, W., de Tapia, M., Kauffmann, S., Montasser-Kouhsari, S., and Burkard, G. 1988. Identification and characterization of maize pathogenesis-related proteins. Four maize PR proteins are chitinases. Plant Mol. Biol. 11:529-538.

Neuhoff, V., Arold, N., Taube, D., and Ehrhardt, W. 1988. Improved staining of proteins in polyacrylamide gels including isoelectric focusing gels with clear background at nanogram sensitivity using Coomassie Brilliant Blue G-250 and R-250. Electrophoresis 9:255262.

Niebel, A., de Almeida Engler, J., Tire, C., Engler, G., Van Montagu, M., and Gheysen, G. 1993. Induction patterns of an extensin gene in tobacco upon nematode infection. Plant Cell 5:1697-1710.

Nishizawa, Y., and Hibi, T. 1991. Rice chitinase gene: cDNA cloning and stress-induced expression. Plant Sci. 76:211-218.

Oka, Y., Chet, I., and Spiegel, Y. 1996. Protein expression in cereal plants infested with the cereal cyst nematode, Heterodera avenae. (Abstr.) Phytoparasitica 24:117.

Opperman, C. H., Taylor, C. G., and Conkling, M. A. 1994. Root-knot nematode-directed expression of a plant root-specific gene. Science 263:221-223.

Parsons, T. J., Bradshaw, H. D., and Gordon, M. P. 1989. Systemic accumulation of specific mRNAs in response to wounding in poplar trees. Proc. Natl. Acad. Sci. USA 86:7895-7899.

Peever, T. L., and Higgins, V. J. 1989. Electrolyte leakage, lipoxygenase, and lipid peroxidation induced in tomato leaf tissue by specific and nonspecific elicitors from Cladosporium fluvum. Plant Physiol. 90: 867-875.

Penninckx, I. A. M. A., Eggermont, K., Terras, F. R. G., Thomma, B. P. H. J., De Samblanx, G. W., Buchala, A., Metraux, J.-P., Manners, J. M., and Broekaert, W. F. 1996. Pathogen-induced systemic activation of a plant defensin gene in Arabidopsis follows a salicylic acidindependent pathway. Plant Cell 8:2309-2323.

Rafi, M. M., Zemetra, R. S., and Berger, P. H. 1996. Jasmonic acidmethyl ester-induced protein profile modifications in wheat (Triticum aestivum L.). Acta Physiol. Plant. 18:53-58.

Rahimi, S., Perry, R. H., and Wright, D. J. 1993. Induction and detection of pathogenesis-related proteins in leaves and roots of potato plants infected with pathotypes of Globodera pallida. Fundam. Appl. Nematol. 16:549-556.

Rahimi, S., Perry, R. N., and Wright, D. J. 1996. Identification of pathogenesis-related proteins induced in leaves of potato plants infected with potato cyst nematodes, Globodera species. Physiol. Mol. Plant
Pathol. 49:49-59.

Raikhel, N. V., and Broekaert, W. F. 1993. Chitin binding proteins, their biology and possible function. Pages 407-423 in: Control of Plant Gene Expression. D. P. S. Verma, ed. CRC Press, Boca Raton, FL.

Raikhel, N. V., and Lee, H. I. 1993. Structure and function of chitinbinding proteins. Annu. Rev. Plant Physiol. Plant Mol. Biol. 44:591615.

Reinbothe, S., Mollenhauer, B., and Reinbothe, C. 1994. JIPs and RIPs: The regulation of plant gene expression by jasmonates in response to environmental cues and pathogens. Plant Cell 6:1197-1209.

Samac, D. A., Hironaka, C. M., Yally, P. E., and Shah, D. M. 1990. Isolation and characterization of the genes encoding basic and acidic chitinase in Arabidopsis thaliana. Plant Physiol. 93:907-914.

Schlumbaum, A., Mauch, F., Vogeli, U., and Boller, T. 1986. Plant chitinases are potent inhibitors of fungal growth. Nature (London) 324:365-367.

Sembdner, G., and Parthier, B. 1993. The biochemistry and the physiological and molecular action of jasmonates. Annu. Rev. Plant Physiol. Plant Mol. Biol. 44:569-589.

Siedow, J. N. 1991. Plant lipoxygenase: Structure and function. Annu. Rev. Plant Physiol. Plant Mol. Biol. 42:145-188.

Staswick, P. E., Huang, J., and Rhee, Y. 1991. Nitrogen and methyl jasmonate induction of soybean vegetative storage protein genes. Plant Physiol. 96:130-136.

Stinissen, H. M., Peumans, W. J., and Carlier, A. R. 1983. Occurrence and immunological relationship of lectins in gramineous species. Planta 159:105-111.

Towbin, H., Staehelin, T., and Gordon, J. 1979. Electrophoretic transfer of proteins from polyacrylamide gels to nitrocellulose sheets: Procedure and some applications. Proc. Natl. Acad. Sci. USA 76:43504354.

Van der Eycken, W., de Almeida Engler, J., Inze, D., Van Montagu, M., and Gheysen, G. 1996. A molecular study of root-knot nematodeinduced feeding site. Plant J. 9:45-54.

Volkmar, K. M. 1991. Abscisic acid and ethylene increase in Heterodera avenae-infected tolerant or intolerant oat cultivars. J. Nematol. 23: 425-431.

Yamamoto, H., and Tani, T. 1986. Possible involvement of lipoxygenase in the mechanism of resistance of oats to Puccinia coronata avenae. J. Phytopathol. 116:329-337.

Zacheo, G., and Bleve-Zacheo, T. 1995. Plant-nematode interactions: histological, physiological and biochemical interactions. Pages 321353 in: Pathogenesis and Host Specificity in Plant Diseases: Histopathological, Biochemical, Genetic and Molecular Bases. Vol. 2. Eukaryotes. K. Kohmoto, U. S. Singh, and R. P. Singh, eds. Pergamon Press, Oxford. 